\title{
Competency based assessment in pharmacology: implications of changed recommendations in viva voce and internal assessment
}

\author{
Gurudas Khilnani $^{1}$, Ajeet Kumar Khilnani ${ }^{2 *}$, Rekha Thaddanee ${ }^{3}$
}

\begin{abstract}
${ }^{1}$ Department of Pharmacology, ${ }^{2}$ Department of Otorhinolaryngology, ${ }^{3}$ Department of Pediatrics, Gujarat Adani Institute of Medical Science and GK General Hospital, Bhuj, Kachchh, Gujarat, India
\end{abstract}

Received: 25 January 2020

Accepted: 05 March 2020

\author{
*Correspondence: \\ Dr. Ajeet Kumar Khilnani, \\ Email: ajeetkhilnani@gmail.com
}

Copyright: $\odot$ the author(s), publisher and licensee Medip Academy. This is an open-access article distributed under the terms of the Creative Commons Attribution Non-Commercial License, which permits unrestricted non-commercial use, distribution, and reproduction in any medium, provided the original work is properly cited.

\begin{abstract}
The competency based assessment (CBA) is an integral part of competency based medical education (CBME). It is important to discern the similarities and differences between CBME and traditional curriculum for developing effective implementation schedules and to identify opportunities for best use of the CBA in pharmacology training. CBA relies on assessment of core competencies and attitudes. The viva marks, to be decided at university level, are excluded from theory marks. An advantage of CBA is early entry of failed students into next phase of study. The areas of concern are, viva marks are included in practical marks further reducing ratio of practical to theory marks despite increase in total marks, and non-contribution of internal assessment marks to university marks for rank or grades. Multiple assessments using multiple tools in limited duration of 11 months would pose logistic problems and would require concerted efforts of faculty members for accomplishment.
\end{abstract}

Keywords: Assessment, Competency, Medical education, Pharmacology, Viva voce

\section{INTRODUCTION}

The Medical council of India (MCI) has recently introduced competency based medical education (CBME) incorporating new curriculum which is student centric and focuses on competencies as outcomes. The new curriculum is implemented with effect from $1^{\text {st }}$ August, 2019 for first professional MBBS year and shall be introduced phase wise subsequently in next phases of MBBS course. A characteristic of CBME is teaching and assessment focus on context of competency and it emphasizes greatly on longitudinally integrated assessment termed as competency based assessment (CBA). Assessment is evidence based, participatory and criteria referenced. Thus, both internal (IA) and University assessments (UA) are modified accordingly.
The objectives of this work were to analyse and compare UA patterns between traditional and new CBA, to identify advantages and limitations of new CBA, evaluate how these changes would affect assessment outcomes, identify opportunities for best use of the CBA in pharmacology training of undergraduate medical students and identify potential areas where we require further clarification for effective assessment in pharmacology.

\section{METHODS}

For the purpose we have selected assessment marks from the Graduate Medical Education Regulation, 1997 (GME-97) and CBME modules provided by the MCI. ${ }^{1-3}$ The distribution of marks in theory and practicals, IA and viva voce are tabulated and analysed. The differences in 
examination pattern, mark distribution between GME1997 and CBME-2019 were also compared. For this comparison and the subjects with similar mark distribution in CBA are clubbed in three groups as shown in Table 3a.

\section{RESULTS}

The major differences in assessment between Traditional (TC) and CBME curricula are shown in the Table 1.

Table 1: Assessment of students' performance: differences between traditional and CBME curricula.

\begin{tabular}{|c|c|c|}
\hline Item & GME-1997 (TC) & CBME-2019 \\
\hline Design & $\begin{array}{l}\text { To ascertain whether the candidate has acquired the } \\
\text { necessary knowledge, minimum skills along with clear } \\
\text { concepts of the fundamentals which are necessary for him } \\
\text { to carry out his professional day to day work competently }\end{array}$ & $\begin{array}{l}\text { To ascertain necessary knowledge, minimal level } \\
\text { of skills, ethical and professional values }\end{array}$ \\
\hline Objectivity & Evaluation will be carried out on an objective basis & $\begin{array}{l}\text { Assessment shall be carried out on objective } \\
\text { basis to the extent possible }\end{array}$ \\
\hline Types of questions & $\begin{array}{l}\text { Preferably short answer (structure) type/ objective type } \\
\text { and marks for each part indicated separately }\end{array}$ & $\begin{array}{l}\text { Structured essays-long answer questions } \\
\text { (LAQs), short answer questions (SAQs) and } \\
\text { multiple-choice questions (MCQs), } \\
\text { problem and/or case based LAQs and MCQs }\end{array}$ \\
\hline Weightage of MCQs & Not stated & Not more than $20 \%$ \\
\hline $\begin{array}{l}\text { Pass criteria in } \\
\text { subject }\end{array}$ & $\begin{array}{l}\text { In each of the subject, a candidate must obtain } 50 \% \text { in } \\
\text { aggregate with a minimum of } 50 \% \text { in Theory including } \\
\text { orals and minimum of } 50 \% \text { in Practicals. }\end{array}$ & $\begin{array}{l}\text { - Secure at least } 40 \% \text { marks in each of two } \\
\text { papers of subject but } 50 \% \text { aggregate marks to } \\
\text { pass. - Mandatory } 50 \% \text { marks in theory and } \\
\text { practical (practical=practical/clinical + viva) }\end{array}$ \\
\hline Practical/clinicals & $\begin{array}{l}\text { - Assess proficiency in skills, conduct of experiment, } \\
\text { interpretation of data and logical conclusion. } \\
\text { - Clinical cases should preferably include common } \\
\text { diseases not esoteric syndromes or rare disorders. - } \\
\text { Emphasis should be on candidate's capability in eliciting } \\
\text { physical signs and their interpretation. }\end{array}$ & $\begin{array}{l}\text { - Common diseases; Ability to elicit history, } \\
\text { demonstrate physical signs, write case record, } \\
\text { analyse the case and develop management plan }\end{array}$ \\
\hline Viva voce & $\begin{array}{l}\text { - Viva/oral includes evaluation of management approach } \\
\text { and handling of emergencies. } \\
\text { - Candidate's skill in interpretation of common } \\
\text { investigative data, X-rays, identification of specimens, } \\
\text { ECG. }\end{array}$ & $\begin{array}{l}\text { - Approach to patient management of } \\
\text { emergencies. } \\
\text { - Attitude, ethics and professional values } \\
\text { - Interpretational skills (Investigation data, } \\
\text { specimen identification and ECG) }\end{array}$ \\
\hline $\begin{array}{l}\text { Inclusion of Viva } \\
\text { marks }\end{array}$ & $\begin{array}{l}\text { For pass criteria (of } 50 \% \text { ) viva is included in Theory. } \\
\text { Thus, viva contributed in passing theory }\end{array}$ & $\begin{array}{l}\text { Practicals/clinicals. It does not contribute in } \\
\text { theory passing }\end{array}$ \\
\hline $\begin{array}{l}\text { Examinations: main } \\
\text { and supplementary }\end{array}$ & $\begin{array}{l}\text { There shall be one main examination in a year and a } \\
\text { supplementary to be held not later than } 6 \text { months after the } \\
\text { publication of its results. }\end{array}$ & \\
\hline First MBBS & $\begin{array}{l}\text { The supplementary examination for } 1^{\text {st }} \text { Professional MBBS } \\
\text { examination may be conducted within } 6 \text { months so that the } \\
\text { students who pass can join the main batch and the failed } \\
\text { students will have to appear in the subsequent year } \\
\text { provided that the students who pass the supplementary } \\
\text { examination shall be allowed to appear in the second } \\
\text { professional MBBS examination only after he/she } \\
\text { completes the full course of study of three semesters (i.e. } \\
18 \text { months) for the second professional MBBS examination } \\
\text { irrespective of the examination of the main batch. }\end{array}$ & $\begin{array}{l}\text { One main and supplementary to be held not later } \\
\text { than } 90 \text { days after declaration of results of main } \\
\text { examinations }\end{array}$ \\
\hline $\begin{array}{l}\text { Weightage of } \\
\text { internal assessment }\end{array}$ & $20 \%$ of total marks in subject & $\begin{array}{l}\text { The internal assessment marks for each subject } \\
\text { will be out of } 100 \text { for theory and out of } 100 \text { for } \\
\text { practical/clinical (except in General Medicine, } \\
\text { General Surgery and Obstetrics \& Gynaecology, } \\
\text { in which theory and clinical will be of } 200 \text { marks } \\
\text { each). }\end{array}$ \\
\hline $\begin{array}{l}\text { IA eligibility to } \\
\text { appear in } \\
\text { university } \\
\text { examination }\end{array}$ & $\begin{array}{l}\text { Student must secure at least } 35 \% \text { marks of the total marks } \\
\text { fixed for internal assessment in a particular subject in } \\
\text { order to be eligible to appear in final university } \\
\text { examination of that subject. }\end{array}$ & $\begin{array}{l}\text { Learners must secure at least } 50 \% \text { marks of the } \\
\text { total marks (combined in theory and } \\
\text { practical/clinical; not less than } 40 \% \text { marks in } \\
\text { theory and practical separately) assigned for } \\
\text { internal assessment in a particular subject }\end{array}$ \\
\hline $\begin{array}{l}\text { Contribution of IA } \\
\text { marks in University } \\
\text { Examination marks }\end{array}$ & $\begin{array}{l}\text { To be added in University theory and practical/clinicals } \\
\text { marks respectively }\end{array}$ & $\begin{array}{l}\text { IA marks are not to be added to marks of the } \\
\text { University examinations. IA marks will reflect } \\
\text { as separate head of passing at the summative } \\
\text { examination }\end{array}$ \\
\hline
\end{tabular}


Table 2: Comparative subject wise marks distribution in university examination.

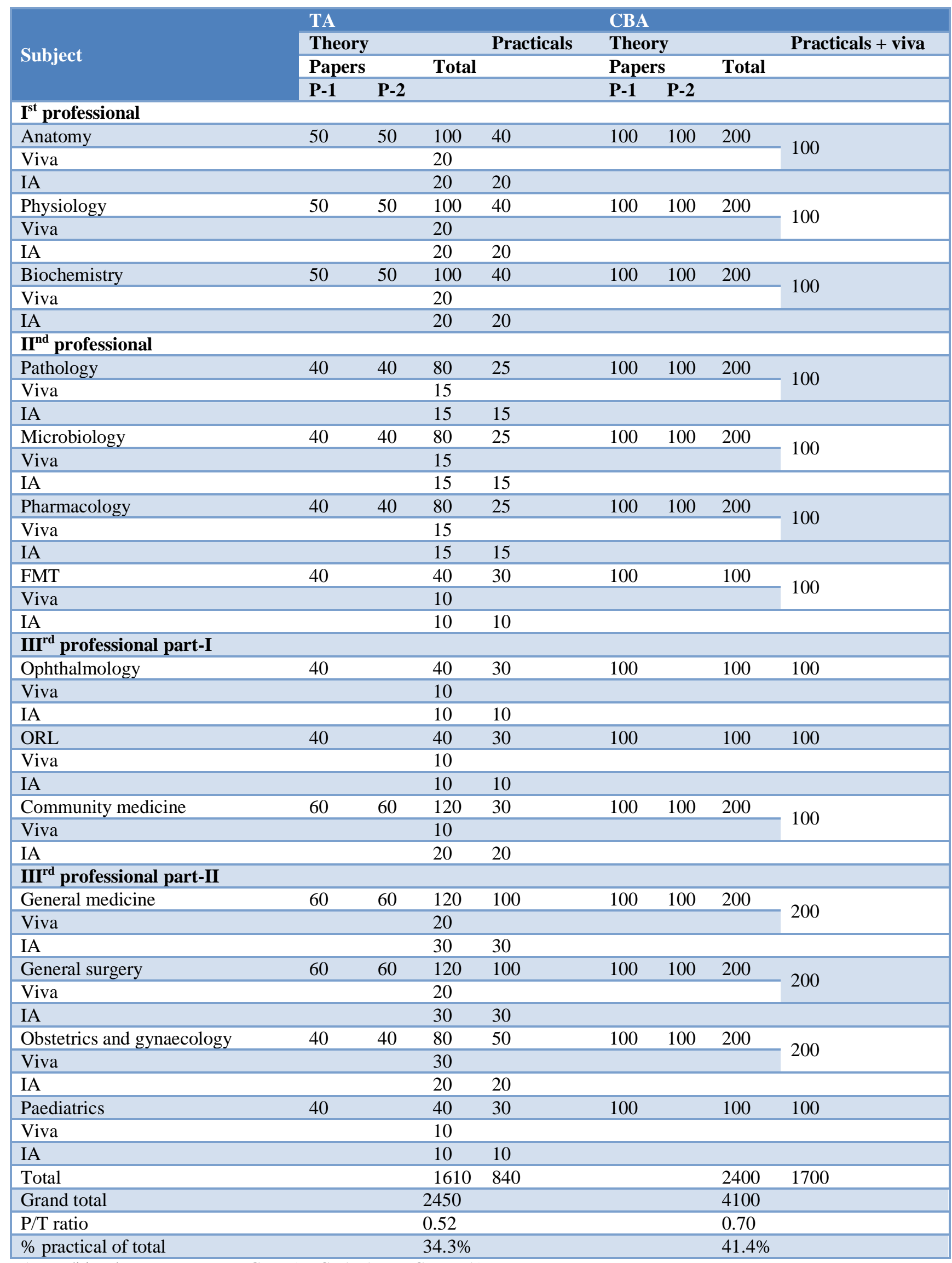

$\mathrm{TA}=$ Traditional assessment as per GME-97, CBA=As per CBME-19. 
The key features of CBA are assessment of attitudes, introduction of problem/case based long answer questions (LAQs) and MCQs, minimum $40 \%$ marks in each of two theory papers and $50 \%$ in aggregate, exclusion of viva marks from theory marks, introduction of supplementary examinations within 90 days of declaration of university results in all phases, no contribution of IA in Theory/practical marks (albeit 50\% required for pass criteria), and emphasis on integrated longitudinal formative assessment.

The comparative mark distribution between traditional assessment (TA) and CBA is shown in Table 2. It is clear that total, theory and practical marks have increased by $70 \%, 49 \%$ and $100 \%(+1650,+790$ and +860 respectively), but the proportion of practicals/clinicals has increased only modestly from $34.4 \%$ to $41.4 \%$.
Inclusion of viva marks in practical marks in pharmacology in $\mathrm{CBA}$

In TA, viva marks contributed to theory marks by $10 \%$ of total marks. Unlike TA, exact marks of viva are not stated in Module- 3 of CBME. ${ }^{2}$ Overall there can be four options (Table 3a):

- Option A: $10 \%$ of total marks as viva marks (30 out of 300) included in practicals, thus making practicals of 70 only.

- Option B: $10 \%$ of Practical marks as viva marks, i.e., 10 marks included in practical marks, thus making practicals of 90 marks.

- Option C: Add $10 \%$ of total marks to practicals, thus total practical marks are 130 .

- Option D: Add 10\% of Practical marks to make total practical marks as 110 .

Table 3a: Impact of addition of viva marks on practical/clinical marks.

\begin{tabular}{|c|c|c|c|c|}
\hline \multirow[t]{2}{*}{ Subjects } & \multirow[t]{2}{*}{ Viva marks options } & \multicolumn{3}{|c|}{ Marks } \\
\hline & & Viva & Practicals & Total \\
\hline \multirow{4}{*}{$\begin{array}{l}\text { Group-A Subjects (300 } \\
\text { Marks) }\end{array}$} & A: $10 \%$ viva of total marks & 30 & 70 & 100 \\
\hline & B: $10 \%$ of practicals & 10 & 90 & 100 \\
\hline & C: Add $10 \%$ of total & 30 & 100 & 130 \\
\hline & D: Add $10 \%$ of practicals & 10 & 100 & 110 \\
\hline \multirow{4}{*}{$\begin{array}{l}\text { Group-B subjects ( } 200 \\
\text { marks) }\end{array}$} & A: $10 \%$ viva of total marks & 20 & 80 & 100 \\
\hline & B: $10 \%$ of practicals & 10 & 90 & 100 \\
\hline & C: Add $10 \%$ of total & 20 & 100 & 120 \\
\hline & D: Add $10 \%$ of practicals & 10 & 100 & 110 \\
\hline \multirow{4}{*}{$\begin{array}{l}\text { Group-C subjects (400 } \\
\text { Marks) }\end{array}$} & A: $10 \%$ viva of total marks & 40 & 160 & 200 \\
\hline & B: $10 \%$ of practicals & 20 & 180 & 200 \\
\hline & C: Add $10 \%$ of total & 40 & 200 & 240 \\
\hline & D: Add $10 \%$ of practicals & 20 & 200 & 220 \\
\hline
\end{tabular}

Table 3b: Impact of including viva marks to practicals/clinicals (option-A).

\begin{tabular}{|lllllllll|}
\hline Subject & $\begin{array}{l}\text { TA } \\
\text { Theory } \\
\text { + IA }\end{array}$ & Viva & $\begin{array}{l}\text { Practicals } \\
\text { + IA }\end{array}$ & $\begin{array}{l}\text { P/T } \\
\text { ratio* }\end{array}$ & Theory & $\begin{array}{l}\text { Practical } \\
\text { + viva }\end{array}$ & $\begin{array}{l}\text { Actual marks } \\
\text { in practicals* }\end{array}$ & $\begin{array}{l}\text { P/T } \\
\text { ratio* }\end{array}$ \\
\hline Anatomy & 120 & 20 & 60 & 0.5 & 200 & 100 & 70 & 0.35 \\
\hline Physiology & 120 & 20 & 60 & 0.5 & 200 & 100 & 70 & 0.35 \\
\hline Biochemistry & 120 & 20 & 60 & 0.5 & 200 & 100 & 70 & 0.35 \\
\hline Microbiology & 95 & 15 & 40 & 0.42 & 200 & 100 & 70 & 0.35 \\
\hline Pathology & 95 & 15 & 40 & 0.42 & 200 & 100 & 70 & 0.35 \\
\hline Pharmacology & 95 & 15 & 40 & 0.42 & 200 & 100 & 70 & 0.35 \\
\hline FMT & 50 & 10 & 40 & 0.80 & 100 & 100 & 80 & 0.8 \\
\hline Ophthalmology & 50 & 10 & 40 & 0.80 & 100 & 100 & 80 & 0.8 \\
\hline ORL & 50 & 10 & 40 & 0.80 & 100 & 100 & 80 & 0.8 \\
\hline PSM & 140 & 10 & 50 & 0.36 & 200 & 100 & 70 & 0.35 \\
\hline General Medicine & 150 & 20 & 130 & 0.86 & 200 & 200 & 160 & 0.80 \\
\hline General Surgery & 150 & 20 & 130 & 0.86 & 200 & 200 & 160 & 0.80 \\
\hline Obstetrics and gynaecology & 100 & 30 & 70 & 0.70 & 200 & 200 & 160 & 0.80 \\
\hline Paediatrics & 50 & 10 & 40 & 0.80 & 100 & 100 & 80 & 0.80 \\
\hline Total & 1385 & 225 & 840 & $0.60 *$ & 2400 & 1700 & 1290 & $0.53 *$ \\
\hline Grand total & 1610 & & & $0.52 * *$ & & & $0.70 * *$ \\
\hline
\end{tabular}

*P/T ratio of actual marks in practicals (minus viva marks) divided by theory marks, **P/T with viva included in practicals. 
Table 3c: Impact of including viva marks to practicals/clinicals (option-C).

\begin{tabular}{|lllllllll|}
\hline Subject & $\begin{array}{l}\text { TA } \\
\text { Theory } \\
\text { +IA }\end{array}$ & Viva & $\begin{array}{l}\text { Practicals } \\
\text { +IA }\end{array}$ & $\begin{array}{l}\text { P/T } \\
\text { ratio* }\end{array}$ & Theory & Practical & $\begin{array}{l}\text { Practicals } \\
\text { +viva }\end{array}$ & $\begin{array}{l}\text { P/T } \\
\text { ratio* }\end{array}$ \\
\hline Anatomy & 120 & 20 & 60 & 0.5 & 200 & 100 & 130 & 0.50 \\
\hline Physiology & 120 & 20 & 60 & 0.5 & 200 & 100 & 130 & 0.50 \\
\hline Biochemistry & 120 & 20 & 60 & 0.5 & 200 & 100 & 130 & 0.50 \\
\hline Microbiology & 95 & 15 & 40 & 0.42 & 200 & 100 & 130 & 0.50 \\
\hline Pathology & 95 & 15 & 40 & 0.42 & 200 & 100 & 130 & 0.50 \\
\hline Pharmacology & 95 & 15 & 40 & 0.42 & 200 & 100 & 130 & 0.50 \\
\hline FMT & 50 & 10 & 40 & 0.80 & 100 & 100 & 120 & 1.00 \\
\hline Ophthalmology & 50 & 10 & 40 & 0.80 & 100 & 100 & 120 & 1.00 \\
\hline ORL & 50 & 10 & 40 & 0.80 & 100 & 100 & 120 & 1.00 \\
\hline PSM & 140 & 10 & 50 & 0.36 & 200 & 100 & 130 & 0.50 \\
\hline General medicine & 150 & 20 & 130 & 0.86 & 200 & 200 & 240 & 1.00 \\
\hline General surgery & 150 & 20 & 130 & 0.86 & 200 & 200 & 240 & 1.00 \\
\hline $\begin{array}{l}\text { Obstetrics and } \\
\text { gynaecology }\end{array}$ & 100 & 30 & 70 & 0.70 & 200 & 200 & 240 & 1.00 \\
\hline Paediatrics & 50 & 10 & 40 & 0.80 & 100 & 100 & 120 & 1.00 \\
\hline Total & 1385 & 225 & 840 & $0.60^{*}$ & 2400 & 1700 & 2110 & $0.70^{*}$ \\
\hline Grand total & 1610 & & & $0.52^{* *}$ & & & & $0.88^{* *}$ \\
\hline
\end{tabular}

*P/T ratio of actual marks in practicals (minus viva marks); ** $\mathrm{P} / \mathrm{T}$ with viva included in practicals

It is evident that inclusion of viva marks in practicals of 100 marks (option-A) would reduce the P/T ratio from 0.6 of traditional curriculum to 0.53 in CBME curriculum (Table 3b). Operating option $\mathrm{C}$ would obviate this alteration and a $\mathrm{P} / \mathrm{T}$ ratio of 0.7 , which is greater than that of TA (0.6), would be there (Table 3c). This would signify that students shall pay more attention to skill acquisition as well. However, operating option $\mathrm{C}$ would increase total practical marks by $20-30 \%$, as against the recommended 100 marks in CBA.

\section{DISCUSSION}

The traditional pharmacology curriculum was subject centred and time based. ${ }^{4}$ The evaluation was intermittent in the form of assessment of discrete behaviours mostly knowledge, application and psychomotor activity with less opportunities for reflection and feedback. The basic tenement of CBME is competency (outcome) and CBA includes knowledge, skills and attitudes, all assessed simultaneous as a whole pharmacological entity. The assessment is continuous, longitudinal and formative, thus, it is criteria referenced rather than norm referenced. The purpose is to improve learning and ability to utilize acquired knowledge and skills for patient care. However, the CBA becomes inherently less objective and yet more valid than traditional assessment existed in past. ${ }^{5}$ This is because CBA prioritizes assessment for learning in domains higher than knowledge acquisition and include psychomotor, communication, and affective domains. These domains can be tested by multiple tools (assessment tool box) and not simply by an OSCE/OSPE station or practicals only and involves number of examiners. ${ }^{6}$ This obviously makes such assessment variable and less objective. However, use of multiple tools, alignment with objectives within a competency and inbuilt provision for feedback make such assessment to be more valid, i.e., it assesses what it is intended for, that is development of given competency (outcome). It is a new beginning and both students and faculty would take time to get programmed to CBA. Conventionally, students would study those topics of the subject which are given greater weightage or are repeated in university examinations. The marks are the quantitative indicators of achievement of students' performance. Distribution of marks in pharmacology shows that practicals contribute $33 \%$ of total marks (100 out of 300) in CBA as against $26 \%$ (40 out of 150 ) marks of TA. However, this $10 \%$ increase in new curriculum is annulled by inclusion of viva marks in practicals. Thus, if viva marks are subtracted from practicals, (Option-A, Table 3a), actual practical marks are reduced to 70. In GME 1997, the practical marks in pharmacology were 40 out of which IA contribute 15 marks. Total theory marks (Theory plus viva) were 95 . This gives $\mathrm{P} / \mathrm{T}$ ratio of 0.42 , as against CBA P/T ratio of 0.35 with exclusion of viva from practical marks (Table 3b). Furthermore, viva voce has known by limitations such as lack of objectivity, greater inter-rater variability, leniency, central tendency, time consumption and testing of lower cognitive domain of learning. ${ }^{7}$ A potential fallout of this could be that students shall pay less attention to practicals than they used to in TA. This is despite the fact the CBA focuses on process of learning and wholesome assessment for learning.

\section{Internal assessment in $\mathrm{CBA}$}

Traditionally, IA consisted of $20 \%$ of total marks in pharmacology divided equally in theory and practicals and a candidate should get $35 \%$ aggregate marks to be 
eligible to appear in University examination. IA marks contributed to overall grades (Marks) of university examination. In sharp contrast to this, the CBA states "learner must secure at least $50 \%$ of total marks (combined in theory and practicals; not less than $40 \%$ marks in theory and practicals separately) assigned in pharmacology in order to be eligible for appearing at the final University examination. IA will reflect as separate head of passing at the summative examination." 3 Studies have shown that IA has predictive value and there is a positive correlation between continuous internal assessment and final university marks. ${ }^{8}$ However, the CBA has assigned it as a norm for passing University examination without contributing to grades. A lot of effort is needed for a continuous formative assessment and it involves all faculty members in conducting theory and practicals and designing assessment tools. Both the students and faculty feel discouraged by non-normative nature of IA in CBA.

In CBME curriculum the duration of second professional MBBS is 11 months beginning from $\mathrm{I}^{\text {st }}$ October and then there shall be preliminary and university examinations in the month of September. During these 11 months the students shall have to appear in two IA examinations in each of three main subjects (pharmacology, pathology and microbiology). They would also undergo formative assessment tests not only in these subjects but also in subjects which are taught in more than one phase (albeit contribution shall be proportionate). ${ }^{3}$ That means two IAs each for General Medicine, General Surgery, Obstetrics and Gynaecology, Forensic Medicine and Community Medicine, with a total of 16 IAs in 11 months. It would require meticulous preparation of teaching and assessment schedules.

\section{Implications of taking supplementary examination not later than 90 days after declaration of results}

Traditionally, supplementary examinations are taken within 6 months after the declaration of results. In new CBA, the university shall take supplementary examination not later than 90 days after declaration of results. There are advantages and disadvantage to this effect. An advantage is to those students who failed in the first professional MBBS examinations and reappeared soon in supplementary examination and pass shall be able to join with the main batch early in second professional MBBS studies. A similar advantage will be for those students who have failed in second, and final-I professional MBBS examinations and kept term. They shall be able to join earlier with the colleagues for next phase of studies. In the same token, the students failing in final-II examination shall be able to reappear soon (within 90 days) after the results are declared and undergo internship. Traditionally, they had to wait for upto 6 months for reappearing in University examinations. A potential disadvantage is that students who have not been able to perform well after a yearlong study will be required to appear in supplementary examinations again after about a month of declaration of results.

Thus, little time is available for them to adequately prepare in the failed subjects, particularly when they failed in 2-3 subjects. There is another question to be addressed. If department arranges one extra send-up examination for the failed students, it has to be arranged as early as possible (2-3 weeks) after the results are declared. University or Institution shall make necessary preparations for such supplementary examinations..

\section{Implications of inclusion of viva marks in practicals}

The GME-97 regulations recommended viva to be included in theory marks for passing university examinations and the practice was followed in many universities in India. As a matter of convenience the theory viva sessions were arranged during university practical examinations so that both external and internal examiners participated and degree of inter-rater variability was reduced. Practical viva, i.e., viva on exercise, has been a part of practical/clinical examination and the marks were included in practicals/clinicals.

In new UG curriculum, viva marks shall be included with practicals $($ practicals $=$ practical $/$ clinical + viva $)$. It is not clear that actual practical marks shall be total allotted minus viva or total allotted plus viva! Assuming that the same weightage of $10 \%$ is given in CBME curriculum as in TA, the addition of viva marks in practicals shall increase the total practical marks. Conversely, practical marks shall be reduced if viva marks are part of 100 marks in practicals. Since viva marks are to be determined by institutions or universities there will be variable expression of practical pharmacology marks in mark sheets. There is a need for a module for programmatic assessment in pharmacology to be utilized uniformly by all universities.

A unique feature of CBA is greater flexibility of decision making given to universities and institutions to design methodology, assign IA and viva marks. Universities shall also guide the colleges regarding formulating policies for remedial measures for students who are either not able to score qualifying IA marks or have missed on some assessments due to any reason. Therefore, a degree of heterogeneity shall be added due to marked interuniversity variability. For example the Rajiv Gandhi University of Health sciences, Karnataka, has already published revised ordinance pertaining to MBBS course from academic year 2019-20 for first Professional MBBS. ${ }^{9}$ The practical marks are shown as 80 with 40 marks for viva voce making total practical marks as 120 . The University marks distribution in CBA for pharmacology is same as in preclinical subjects. Thus, it may be assumed that the above shall represent practical marks distribution in pharmacology also. It is likely that other universities would assign viva marks as per the 
recommendations of academic councils which would not be same, thus adding element of disparity.

Among the six key features of CBME/CBA [continuous and formative, criteria referenced, work-based, use of reliable assessment tools, qualitative (judgement and feedback), and multiple assessment tools for pooled inference], using reliable and multiple tools is perhaps a major challenge during formative assessment. ${ }^{5}$ The students and faculty have worked with traditional curriculum for years together and thus have apprehensions about impact of formative assessment/internal assessment in the absence of its contribution in University marks. Will it drift away students from attending classes regularly? Another concern is that we need to know both "what", "when" and "how" to assess in CBA. This is because new CBME format is time bound as well. The real utility of new CBA will be found in due course of time as it is still a "work in progress" and we are still learning!

\section{CONCLUSION}

Competency Based Assessment is ongoing and longitudinal assessment of theory and practicals and it aids in learning pharmacology. It uses a variety of assessment tools and thus is more subjective and valid as compared to traditional assessment. The corresponding changes have been made in assessment framework giving greater autonomy to universities. Possible implications would be inter-university variability in marks assigned to viva and internal assessment. CBA recommends early conduct of supplementary examinations, which is a welcome step. The universities need to design and plan formative assessment in a programmatic manner for effective scheduling in all subjects including pharmacology. The CBME as a whole is still an emerging concept and we are still in a learning phase.

Funding: No funding sources

Conflict of interest: None declared

Ethical approval: Not required

\section{REFERENCES}

1. Medical Council of India. Regulations on graduate medical education, 1997. Available at:
https://old.mciindia.org/Rules-andRegulation/

GME_REGULATIONS.pdf. Accessed on 12 December 2019.

2. Medical Council of India. Assessment Module for Undergraduate Medical Education Training Program, 2019: 1-29.

3. Shah N, Desai C, Jorwekar G, Badyal D, Singh T. Competency-based medical education: An overview and application in pharmacology. Indian $\mathrm{J}$ Pharmacol 2016;48(1):5-9.

4. Holmboe ES, Sherbino J, Long DM, Swing SR, Frank JR. The role of assessment in competencybased medical education. Med Teach. 2010;32:67682.

5. ACGME Toolbox of assessment methods ver 1.0. Available at: https://www.partners.org/Assets/ Documents/Graduate-Medical-Education/ToolTable. Pdf. Accessed on 11 September 2019.

6. Torke S, Abraham RR, Ramnarayan K, Asha K. The impact of viva-voce examination on students' performance in theory component of the final summative examination in physiology. J Physio Pathophysiol. 2010;1:10-2.

7. Khilnani AK, Charan J, Thaddanee R, Pathak RR, Makwana S, Khilnani G. Structured oral examination in pharmacology for undergraduate medical students: Factors influencing its implementation. Indian $\mathbf{J}$ Pharmacol. 2015;47:546-50.

8. Badyal D, Singh S, Singh T. Construct validity and predictive utility of internal assessment inundergraduate medical education. Nat Med J India. 2017;30:151-4.

9. Revised Ordinance Governing MBBS degree course and curriculum of Phase I and II Subjects- 2004. Available at: http://www.rguhs.ac.in/courses_rguhs/ medical_ordinances/mbbs\%20rs4\%20with\%20logbo oks.pdf. Accessed on 12 September 2019.

Cite this article as: Khilnani $\mathrm{G}$, Khilnani AK, Thaddanee R. Competency based assessment in pharmacology: implications of changed recommendations in viva voce and internal assessment. Int J Basic Clin Pharmacol 2020;9:683-9. 